\title{
A telephelyválasztás lehetőségei a szállodaiparban
}

\section{Choice of location in the hotel industry}

\section{ALBERT TÓTH ATTILA, RECHNITZER JÁNOS}

\begin{abstract}
ALBERT TÓTH Attila: egyetemi tanársegéd, Széchenyi István Egyetem, Kautz Gyula Gazdaságtudományi Kar, Turizmus Tanszék; 9026 Győr, Egyetem tér 1.; albert.toth.attila@sze.hu; https://orcid.org/0000-0002-7599-7736

RECHNITZER János: egyetemi tanár, a doktori iskola vezetője, Széchenyi István Egyetem, Regionális- és Gazdaságtudományi Doktori Iskola; 9026 Győr, Egyetem tér 1., rechnitzer.janos@sze.hu; https://orcid.org/0000-0001-7570-4238
\end{abstract}

KULCSSZAVAK: telephelyválasztás; szállodaipar; befektetési döntés; Budapest

ABSZTRAKT: A szálláshelyek telepítési helyének megválasztása a kezdetektől fogva tudatos döntések következménye volt, még akkor is, ha sokáig ez spontán módon ment végbe. Később, a szállodaipar fejlődése során létrejöttek azok a legfontosabb szállodatípusok, amelyek már nagymértékben meg is határozták a telepítési helyüket.

A tanulmány bemutatja a telephelyválasztás modelljeit, a monocentrikus, az agglomerációs és az empirikus modellek, valamint a szállodai gyakorlathoz közel álló működési modellek sajátosságait, abból a célból, hogy elemzési módszereket nyújtson új szállodák létesítéséhez. A budapesti esettanulmány felvázolja a fővárosi szállodaipar 2016-ra kialakult térbeli koncentrációját, valamint vizsgálja a 2008 és 2016 között megnyílt új szállodák telephelyválasztását. Az elemzés kerületi bontásban értékeli a közelmúlt legsikeresebb szállodai beruházásait. A telephelyválasztást és a befektetési döntést befolyásoló tényezők értékelése a gyakorlatban is segítséget nyújthat a szállodai beruházások során. Kockázatos döntéseket kell hozni, amelyek később már nehezen vagy egyáltalán nem korrigálhatók. Nem kétséges, hogy a jó telehelyválasztás a szálloda jövőbeni sikerességét alapvetően meghatározza.

Attila ALBERT TÓTH: assistant lecturer, Department of Tourism, Kautz Gyula Economics Faculty, Széchenyi István University; Egyetem tér 1., H-9026 Győr, Hungary; albert.toth.attila@sze.hu; https://orcid.org/0000-0002-7599-7736

János RECHNITZER: university professor, head of doctoral school, Doctoral School of Regional Sciences and Business Administration, Széchenyi István University; Egyetem tér 1., H-9026 Győr, Hungary; rechnitzer.janos@sze.hu; https://orcid.org/0000-0001-7570-4238

KEYWORDS: choice of location; hotel industry; investment decision; Budapest

ABSTRACT: The selection of a hotel site location has always been the result of conscious decisions, even though some lodgings may have had some more spontaneous beginnings. With the development of hotels and the hotel industry, some distinctive hotel types have evolved, which have had a direct impact on siting. The location to be selected for a new hotel depends largely on the type, character, quality category and the targeted guest groups. The paper aims to

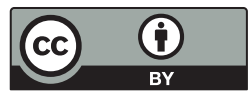


answer two main research questions. What models are available to study the location of hotels and how can they be applied? Which districts in a metropolis have proved to be the most favoured when choosing hotel locations?

The paper discusses the characteristics of the most frequent hotel types and their most favourite locations. The assessment of factors influencing location theory and investment decisions also provide useful practical help in this key decision which later cannot be changed but essentially determines the future success of the hotel. Some common or 'generic' location theories can be adapted for the siting choice of hotels. Apart from the models of hotel selection, the social, technological, environmental, political and legal factors influencing hotel investments, the real estate market situation in the area, and tourism considerations are important when finetuning an investment decision.

The academic literature lays out the features and applicability of essentially four hotel siting models: the mono-centric, the conurbation-based, the empirical and the operational model. The majority of the hotel industry in Budapest is located in a few central popular districts. The location theory applied for the leading Budapest hotels is the mono-centric model. A case study of Budapest outlines the geographic concentration of that part of the hotel industry which had developed until to 2016. It then analyses the location choice of new hotels that were opened between 2008 and 2016. The most successful districts were identified accordingly. The methods of analysis from this study can be effectively applied to feasibility studies and business plans in the hotel industry to determine the optimum location of a new hotel as part of the investment decision-making process.

\section{Bevezetés}

A szállodák telephelyválasztásának kérdései különböző megközelítési szempontok alapján, földrajzi, gazdasági, marketing-, pénzügyi, terület- és településfejlesztési, turisztikai és szállodaimenedzsment-oldalról jelennek meg a szakirodalomban. A helyfoglalási rendszerek, a mobilkommunikáció, a telefonok applikációi alapján készült elemzések a vendégek szállodaválasztását értékelik (Aksoy, Ozbuk 2017; Park, Kim 2012; Yang, Tang, Luo, Law 2015). E körülmények is jelentősen befolyásolhatják a vendégek fogyasztói magatartását, amelyek tapasztalatai végső soron a jövőben létesítendő szállodák telephelyválasztására is hatással lehetnek.

A szállodák telephelyválasztását vizsgáló modellek mellett fontosak a szállodai beruházásokat befolyásoló társadalmi, technológiai, környezeti, politikai, jogi tényezők, az adott terület ingatlanpiaci helyzete, számos turisztikai és szállodaipari szakmai kérdés. A desztinációk versenypiaci helyzetének és a piacon már müködő szállodák versenytársainak elemzését is el kell végezni a telephelyválasztás és a szállodai projekt elindítása előtt.

A szálloda elhelyezkedése a később nem megváltoztatható döntések csoportjába tartozik. A szálloda konkrét telephelyének megválasztása (telek, ingatlan) a szálloda életciklusa alatt meghatározza a szálloda egyik legfőbb adottságát és jelentősen befolyásolja sikerességét. A szálloda elérhetőségét szintén a telephelyválasztás határozza meg, de ez változhat is az idők folyamán, például egy új tömegközlekedési vonal, állomás kiépítésével. 
Mivel egy szálloda ingatlanjellegü befektetés is, nem elhanyagolható szempont az sem, hogy életciklusa alatt - amíg szállodaként, profitorientált vállalkozásként üzemel - hogyan változik az ingatlan értéke. Városi terekben, főként világvárosokban a szálloda telke is felértékelődhet olyan mértékben, hogy a régi, elavult, kevés szobaszámmal rendelkező szállodát szerény jövedelmezőség esetén inkább lebontják, és a helyére új felhőkarcolót építenek, részben vagy egészben szállodafunkcióval. Tehát az alaptevékenységből viszonylag szerény hasznot termelő szálloda is lehet akár egészen kimagasló profitot eredményező befektetés hosszú távon, ha tulajdonosai az ingatlan értékének növekedésére spekulálnak és megfelelő időpontban értékesíteni tudják a szállodát az ingatlanpiacon.

A szállodaipar a turisztikai desztinációk legfontosabb szuprastrukturális elemei közé tartozik és a desztinációk versenyképességét is jelentős mértékben befolyásolja (Albert Tóth 2016). A szállodák jól megválasztott telepítési helye szükséges előfeltétele a sikeres turisztikai desztináció kialakításának.

A tanulmány két fő kutatási kérdésre keresi a választ. Az egyik, hogy a szállodák telephelyválasztásának tanulmányozásához milyen modellek állnak rendelkezésre, és ezek általánosságban használhatók-e. E kutatási kérdés megválaszolásához a szakirodalmi áttekintés nyújt támpontot. A másik kérdés, hogy mely budapesti kerületek a legvonzóbbak a szállodák telepítési helyének megválasztásakor, illetve hogy az utóbbi évek szállodaberuházásainál a befektetők figyelembe vették-e már a működő szállodák sikerességét. A budapesti esettanulmány a legfontosabb szállodai mutatószámok és az újabb szállodai beruházások területi koncentrációjának értékelésével keresi a válaszokat.

\section{Telephelyválasztás és lokalizációs modellek a szállodaiparban}

A szállodák telephelyválasztásáról viszonylag kevés publikáció jelent meg a nemzetközi és a hazai szakirodalomban. Az ingatlanfejlesztés helyszínének kiválasztása során az elméleti modellek használhatósága is korlátozott a szállodai gyakorlatban (Yang, Luo, Law 2014), mert egyetlen modell sem tudja helyettesíteni egy szálloda telephelyének megválasztásánál a józan mérlegelést.

A szállodák telephelyválasztására is adaptálható modelltípusok a monocentrikus modell, az agglomerációs modell, az empirikus modellek és a szállodai gyakorlathoz közel álló működési modellek. A témával foglalkozó publikációk általában több modelltípust is tartalmaznak, esettanulmányjelleggel egy-egy konkrét helyszín is megjelenik az elemzésekben. A kutatások csaknem fele az urbánus terekkel foglalkozik, általában nagyvárosokban vizsgálja a szállodák elhelyezkedését, telepítési tényezőit.

A monocentrikus modell a városközpontot középpontnak számítva, koncentrikus körgyürük vagy görbék távolságai alapján adja meg az egyes zónákat, 
ahol a különböző típusú és minőségű szállodák találhatók. Yokeno (1968) von Thünen 1826-os klasszikus területhasználati modelljét adaptálta a városi szállodák telephelyválasztására. A modell középpontja a városközpont, ahol egy központi üzleti negyedben vagy közelében, a kereskedelmi zónában találhatók a jelentős szállodák, a központtól távolodva a lakónegyedek, még messzebb az ipari területek, majd a város szélétől a mezőgazdasági célra használt területek helyezkednek el. Az utóbbi zónákban már kevés a szálloda, olcsóbb és egyszerübb szálláshelyek azért itt is találhatók.

A modellt később több szerző is használta egyszerüsége és könnyű alkalmazhatósága miatt (Ashworth, Tunbridge 1990; Egan, Nield 2000; Shoval 2006; Yang, Wong, Wang 2012). Nyugat-európai városokat elemezve Ashworth és Tunbridge (1990) a turisztikai jelentőséggel rendelkező történelmi városok modelljét alakították ki. Hat zónát állapítottak meg egy-egy városon belül: a városkapuk, a vasútállomások, a föutak, a „kellemes helyek”, a városi periferikus utak és a repülőtér közelében található zónát. Ezekben a zónákban különböző jellegű szállodák vannak, a kis és közepes méretű szállodák a „kellemes helyek” zónájában találhatók általában, míg a nagyobb, modern szállodák a periferikus utak és a repülőtér közelében.

Egan és Nield (2000) a kínai nagyvárosokat (Peking, Sanghaj, Sencsen) elemezték e módszerrel, és megállapították, hogy a városi térben a központba települtek a luxusszállodák, attól számítva kisebb távolságban az üzleti szállodák, messzebb pedig az egyszerúbb és olcsóbb szállodák találhatók. A centrum szállodáiban érhetők el a legmagasabb szállodai árak, ahogy a terület értéke, a beépíthető telkek vagy átalakítható épületek ára is csökken a központtól mért távolsággal. Shoval (2006) is a monocentrikus modell alapján elemezte Jeruzsálem szállodáinak telephelyválasztását, és annyiban tovább is fejlesztette a modellt, hogy a városban a szállodák iránt kétféle keresleti zónát állapított meg: az egyéni vendégek és a szervezett turisták által preferált szállodákat.

Yang, Wong és Wang (2012) Pekingben elemezték a szállodák térbeli elhelyezkedését. A kínai fóváros ideális terep a kutatásra, mert a közelmúltban sok új szálloda épült, többek között a 2008-as olimpiai játékok, a kiemelkedő gazdasági növekedés és a turisták Kína iránti egyre fokozódó érdeklődése miatt. A város nagy alapterületű és centrális térszerkezetű, tehát egyszerü, klasszikus eset lehetne, ha nem lenne sok más befolyásoló tényező. A szerzők kiemelik, hogy a szállodák telepítési helyére vonatkozó befektetői döntést nagyban befolyásolja a turisták későbbi várható szállodaválasztása, amelyet a hatalmas város közlekedési lehetőségei jelentősen befolyásolnak. Rámutattak továbbá arra, hogy egy szálloda telepítési helyének megválasztásában igen fontosak a jelenlegi és jövőbeni városfejlesztési tervek, a folyamatban levő infrastrukturális és gazdasági jellegű beruházások.

Az agglomerációs modellek alkalmasak nagyobb területek szállodai telephelyválasztásnak elemzésére. Baum és Haveman (1997) megállapították, hogy amikor egy új szálloda belép egy számára új piacra, nemcsak a telephelyet kell 
megfelelően kiválasztania, hanem ehhez a megfelelő terméket (szállodatípust, szolgáltatásokat) is. New Yorkban, Manhattanben háromféle dimenziót vizsgáltak: a földrajzi távolságokat, az árkülönbségeket és a szállodák méretbeli eltéréseit.

Chung és Kalnins (2001) Texas állam területén vizsgálták a szállodaipart, megállapították, hogy a független szállodáknak előnyük származhat a szállodaláncok jelenlétéből. Az agglomerációs értékelések jellemzően piaci megoszlásokat, a szállodaláncok és a független szállodák arányát, a szállodák kapacitásainak megoszlását, az adott terület népességét és jövedelmi viszonyait vonják be az elemzés körébe. Urtasun és Gutiérrez (2006) ezeket a mutatókat a szolgáltatások változatosságának mérésével bővítették Madrid példáját vizsgálva.

Zhang, Guillet és Gao (2012) a multinacionális szállodaláncok befektetéseinek helyszínválasztását kutatták Kínában. A kutatás nem a városon belüli telephelyválasztást vizsgálta, hanem azt, hogy a szállodavállalatok hol és miért létesítenek új szállodákat, és ez mennyiben járul hozzá az ország és az adott terület gazdasági fejlődéséhez. A tanulmány szerint a gazdaság fejlődésével párhuzamosan a turizmus és a szállodaipar fejlődése is óriási volt Kínában, az előrejelzések szerint 2020-ra az országok között Kína az első számú turisztikai desztináció lehet a világon, ha a jelenlegi trendek folytatódnak. A szállodai beruházások igazolják a kereslet növekedését azokon a területeken, ahol a gazdasági beruházások történnek.

Rubovszky (2009) a magyar szállodaipar 2. világháború utáni történetét dolgozta fel. Időrendi sorrendben, hitelesen dokumentálta szállodaiparunk fejlődéstörténetét, külön kitérve néhány szállodatípus jellegzetességére. A könyvfejezet nem telephelyválasztást vizsgált, de alapműnek számít a magyar szállodaipar területi és strukturális kialakulásának tanulmányozásához.

A magyarországi wellness-szállodák telepítési helyeinek tapasztalatait elemezte egy figyelemre méltó tanulmányban Kátay (2011). A wellness-szállodák viszonylag alacsony összesített foglaltsági mutatói alapján vizsgálta régiós szinten, hogy a szállodákat valóban a megfelelő helyekre telepítették-e, és nem a rossz telepítési döntések járultak-e hozzá a kedvezőtlen foglaltsághoz. Az általa kidolgozott környezetértékelési módszer segítségével a következő tényezőket értékelte: a vonzerőt a vendégéjszakák száma szerint kialakult sorrend alapján; a térségi fejlettséget; a terület turisztikai besorolását; a megközelíthetőséget; a telkek építési kategóriáját; a közművel való ellátottságot; a termálvíz kinyerési lehetőségét; valamint a szállodaipari mutatószámokat a versenytársak összehasonlításával. A tanulmány végén megállapította, hogy nem igazolható egyértelmüen a wellness-szállodák telepítési helyének sikeressége (Kátay 2011).

Az empirikus modellek nagyon változatosak, attól függően, hogy milyen indikátorokat hasonlítanak össze. Jellemző a területi statisztikai modellek, a regressziós modellek, az egyedi értékelő modellek és a szállodasikerességi modellek használata. Egy szálloda sikerességét elsősorban a magas bevételekkel és a jövedelmezőséggel jellemezhetjük, ezért olyan helyen kell felépíteni azt, ahol a már müködő szállodák is képesek kiemelkedő profitot (Biemer, Kimes 1991) elérni. A 
magas átlagárak (Enz, Canina, Liu 2008), a nagyon jó egy kiadható szobára jutó szobaárbevétel már megteremtheti a siker alapját (Tsang, Yip 2009).

Az új piacra való belépés eldöntéséhez a Porter-modell (1990) is jól használható a szállodaiparban, egy adott területen levő verseny, a működő szállodák gazdasági, társadalmi és szállodai szakmai mutatószámainak versenytárselemzésbe vont értékelésével. A szállodáknál egy telített piacon nagy a helyettesíthetőség mértéke, így a kockázat is, de a gyakorlati tapasztalat azt mutatja, hogy egy új szálloda, amely szolgáltatásaival, ár-érték arányával, különleges adottságaival vagy akár egy jó márkanévvel felülmúlja a piacon már működőket, sikeresen bevezethető az adott desztinációban.

A múködési modellek a szállodai gyakorlathoz állnak közel, ezért jól használhatók egy szálloda telephelyének kiválasztásában. Az ellenőrzőlistás módszer már a régebbi szállodás (Medlik 1966; Pandit 1986) és turizmust elemző (Smith 1995) szakirodalmakban is megjelent. Bull (1994) az amerikai piacon vizsgálta az elhelyezkedés hatását a motelek szobaáraira. A marketingben is fontos szerepet kap a jól kiválasztott helyszín, amit a motelek a reklámkommunikációs tevékenységeikben kihasználnak, általában a kis távolságot - a centrumtól, a fürdőtől, a repülőtértől - helyezik előtérbe. A motelek minősége mellett ennek jól kimutatható hatása van az árakra. Minőségben, színvonalban a moteleknél általában nincs akkora eltérés, mint a szállodáknál, ezért a motelek esetében a helyszínnek nagyobb az árra gyakorolt hatása, annak ellenére, hogy ezek a viszonylag olcsó szálláshelyek közé tartoznak. Szükséges megjegyezni, hogy az amerikai piacon kialakultak a motelek városi, elővárosi és üdülőterületen levő változatai is, bár jellemzően ilyen esetekben is a foútvonalak, közlekedési csomópontok közelében találhatók.

Newell és Seabrook (2006) a szállodai befektetői döntés folyamatát elemezték az ausztrál szállodapiacon, szállodai befektetők és szállodát üzemeltetők megkérdezésével. 30 mutató közül a befektetői döntést leginkább befolyásoló tényezők a pénzügyi szempontok (37\%) és az elhelyezkedés (30\%) voltak. Az elhelyezkedés elemzése egyértelműen befektetői célzatú értékelés volt, nem a konkrét telephelyválasztásra, hanem a desztináció piaci lehetőségeire koncentrált. A keresletet (a külföldi és belföldi vendégek számát) és a kínálatot (meglévő szállodai kapacitások), a szállodák állapotát, korát, életciklusát, a hely elérhetőségét, a közlekedési viszonyokat, a konferencialehetőségeket értékelték. A pénzügyi szempontokhoz sorolták a szállodák mutatószámait (egy kiadható szobára jutó szobaárbevétel), a bruttó üzemeltetési eredményeket, a szállodai piaci kockázatot. A tanulmány egyértelműen igazolta, hogy a befektetők számára is az egyik legfontosabb szempont a helyszínválasztás; ez a sikeres, üzletileg nyereséges szálloda egyik kulcstényezője. Emir és Saracli (2014) Törökországban egy helyszínen vizsgálták a termálszállodák lehetséges telepítési helyét. Hierarchia-folyamatelemzés módszerével javasoltak telephelyet. A következő tényezőket vették figyelembe: az épület sajátosságai, környezeti tényezők, versenyhelyzet és versenytársak, demográfiai helyzet, távolságok, a befek- 
tetés költségvonzatai. Ezen belül a legfontosabb altényezők voltak: a területi infrastruktúra, a szálloda távolsága a termálvíztől, a versenytársak, a célcsoport, a megközelíthetőség, az építés költségei. A tanulmány a befektetési döntésekhez nyújtott segítséget egy speciális piacon és területen, de a szerzők is felhívják a figyelmet arra, hogy a javasolt módszer általános érvényessége korlátozott. A legátfogóbb részletes elemzéseket egy erre a témára szakosodott amerikai intézet szerzői (Rushmore, O’Neill, Rushmore Jr. 2012) publikálták, akik csaknem négyszáz oldalon mutatják be a szállodapiaci elemzések, értékelések módszereit és lehetőségeit, segítséget nyújtva egy új szálloda beindításához, beleértve a telephely kiválasztását.

\section{Budapesti szállodák telephelyválasztásai}

Budapest szállodaiparának területi koncentrációja, a szállodák telephelyválasztása a szállodai telephelyválasztási modellek alapján két modellel is jól értékelhető: a monocentrikus modell és az empirikus modellek közül a sikerességi modell alkalmazásával.

A monocentrikus modell alapján a fóváros három fö területegységre osztható: belvárosra, városalközpontokra és a külvárosi térre, ahol a szállodaipar már nem számottevő. A térbeli elhelyezkedés szerint általánosságban, így Budapesten is, megkülönböztethetjük a városközponti (belvárosi), a városalközponti, a pályaudvari, a repülőtéri és a külső, idegenforgalmilag nem frekventált külvárosi területeken levő szállodákat.

A szállodatípusokkal szinte minden szállodás szakkönyv foglalkozik, és a két legfontosabb szállodatípus, a városi szálloda és az üdülőszálloda legfőbb jellemzőit részletesen leírják (Gee 1996; Go, Pine 1995; Gray, Liguori 1990; Győrffy 2004; Hayes, Ninemeier 2004; Jávor 2008; Jones, Lockwood 2004; Kovács 2009; Lundberg 1994; Vadas 2006).

A városi szállodák altípusainak többsége elnevezésében a szálloda elhelyezkedésére, míg más altípusok - az üdülőszállodákhoz hasonlóan - a szálloda jellemző szolgáltatásaira, főbb célcsoportjaira utal. A „városi szálloda” kategória tehát egy gyűjtőfogalom, hiszen sokféle szálloda müködhet városokban, amelyeknek más-más a fó szolgáltatási kínálata és a megcélzott vendégköre.

A szállodatípusok közül általában a városi szállodák integrálódnak leginkább a társadalmi életbe, mert a turisták fogadása mellett többnyire részt vesznek a helyi közösségek rendezvényeinek lebonyolításában is.

Az 1. táblázat áttekinti a Budapestre jellemző legfontosabb szállodatípusokat, és a szállodatípusok telepítési helyének összefüggéseit, néhány konkrét szálloda említésével.

A budapesti szállodaipar történetének feldolgozása során Bártfai (2012) leírta sok régi, de még ma is müködő szálloda építésének körülményeit, pontos 
1. táblázat: A legfontosabb városi szállodatípusok és a telephelyválasztás összefüggései Budapest példáján

Relationship between the most important types of city hotels and choice of location-the example of Budapest

\begin{tabular}{|c|c|}
\hline Szállodatípusok & A telepités helyét meghatározó fontosabb jellemzók \\
\hline Belvárosi szállodák & $\begin{array}{l}\text { A legdrágább telkeken, általában magasabb minőségi kategóriájú } \\
\left.\text { szállodák ( } 4-5^{*}\right) \\
\text { Többek mellett a jelenlegi Duna-parti szállodasor: (Four Seasons } \\
\text { Gresham Palace, Sofitel, InterContinental, Marriott) }\end{array}$ \\
\hline Városalközponti szállodák & $\begin{array}{l}\text { Nagyvárosok alközpontjaiban, közlekedési csomópontokban, jó } \\
\text { minőségű, de nem luxusszállodák (Griff, Hungária) }\end{array}$ \\
\hline Pályaudvari szállodák & $\begin{array}{l}\text { Vasúti vagy autóbusz-pályaudvar mellett, jellemzően } \\
\text { középkategóriájú szállodák (Baross, Golden Park) }\end{array}$ \\
\hline $\begin{array}{l}\text { Konferenciaközpont vagy } \\
\text { vásárközpont szállodái }\end{array}$ & $\begin{array}{l}\text { Konferenciaközpont, kiállítás, vásár mellé vagy közelébe telepített } \\
\text { szállodák, a fő vendégkörük azok a hivatásturisták, akik a } \\
\text { rendezvényeken vesznek részt (Expo Congress) }\end{array}$ \\
\hline Stadionközeli szálloda & Stadion, sportcsarnok közelében levő szálloda (Danubius Arena) \\
\hline $\begin{array}{l}\text { Különleges szolgáltatást } \\
\text { nyújtó szállodák }\end{array}$ & $\begin{array}{l}\text { Például gyógyszálloda, kaszinószálloda, butikhotel, tematikus hotel. } \\
\text { Gyógyszállodák Budapesten (Aquincum, Hélia, Danubius } \\
\text { Margitsziget) }\end{array}$ \\
\hline Repülőtéri szállodák & $\begin{array}{l}\text { Nagyvárosok nemzetközi repülőterein vagy közvetlenül a repülőtér } \\
\text { közelében levő szállodák. Budapesten jelenleg három sorolható } \\
\text { ebbe a kategóriába }\end{array}$ \\
\hline Városszéli szállodák & $\begin{array}{l}\text { Nagyvárosok elővárosaiban vagy külső kerületeiben található, jól } \\
\text { megközelíthető, olcsó szállodák vagy motelek }\end{array}$ \\
\hline
\end{tabular}

helyszíneit. Rubovszkyhoz hasonlóan ő sem a telephelyválasztást vizsgálta, de hozzájárult a telepítési tényezők szempontjainak és a mai budapesti szállodai struktúra kialakulásának megértéséhez. Egy korábbi publikációjában (Bártfai 2007) megállapította, hogy a jelenlegi hivatalos, autóbuszos budapesti városnézés útvonalai mentén kevés szálloda található.

Budapesten a szállodák túlnyomó többsége a belvárosban, ezen belül a centrumban, illetve a belvárost szorosan körülölelő városalközpontokban található. A belvárosban a történelmi városrész szállodai szempontból is értelmezhető Budapesten (Várkerület, Duna-parti szállodasor), de nem olyan egyértelmüen, mint más városok, például Prága esetében (Buceková 2009). A Duna partja, a folyó melletti és a folyó környékén levő utcák számítanak a legfrekventáltabb területnek a szállodai telephelyválasztás szempontjából, így van ez a Duna mellett fekvő négy föváros közül háromban (Pozsony, Budapest, Belgrád), míg Bécsben csak néhány jelentős szálloda található a Duna mellett, mert a belvárosnak tekinthető, a bécsi Ring által határolt terület a folyótól távolabb van (Albert Tóth 2011).

A városalközpontokban működő szállodák is jelentősek Budapesten. Vadas $(2006,83$.$) szerint ez a szállodatípus ,tipikus urbanizációs termék, a nagyváro-$ sok, a megapoliszok kialakulásának következménye". Ebben az övezetben alig 
találhatók luxusszállodák, inkább a kedvezőbb ár-érték arányú, de jó minőségű hotelek jellemzőek.

A monocentrikus modell kiegészíthető az empirikus modellel, a szállodák fontosabb sikerességi mutatószámainak értékelésével. A kerületek adatai alapján pontosan besorolhatók és elemezhetők a szállodai telephelyek a fövárosban. A kerületi besorolást alapul véve, szükebb értelemben belvárosnak az V. kerületet tekintjük: ez a belső magterület, amely a turizmus és a szállodaipar szempontjából a legfontosabb a fóvárosban. Tágabb értelemben még a belvároshoz vagy a belvárost közvetlenül körülvevő belső területekhez sorolhatjuk az I., VI., VII., VIII. kerületeket, de ide tartozhat még a IX. és a XI. kerület egy része is. Az V. kerület kimagasló mutatói minden szempontból szembetűnőek. Itt található a fóváros szállodai szobakapacitásának csaknem negyede (22,5\%), és a luxusszállodáknak köszönhetően a szállodai szobaárbevétel közel 40\%-a is ebben a kerületben realizálódik. A 2. táblázat bemutatja a szállodai telephelyválasztás kerületenkénti adatait, a legfontosabb tíz kerület adatai alapján.

Országos szinten is figyelemre méltó, hogy a vendégéjszakák száma az V. kerületben magasabb, mint Hévízen és Hajdúszoboszlón együttvéve, pedig a két fürdőváros a hazai listán a 2. és a 3. helyet foglalja el (KSH 2016). Az V. kerület olyan turisztikai centrum, amely szállodaiparának rendkívüli koncentráltsága miatt önálló városként országos szinten is első lenne.

A szállodai telephelyválasztás kapcsán a 2. táblázatban szereplő mutatók adják meg legobjektívebben a szállodák telephelyválasztásának üzleti alapon számított sikerességét. Budapesten a legfontosabb tíz kerületen kívüli kerületek

2. táblázat: A budapesti szállodák legfontosabb mutatószámai kerületenként (2016) Hotel performance indicators in Budapest by districts (2016)

\begin{tabular}{lcccccc}
\hline \multicolumn{1}{c}{ Kerület } & \multicolumn{2}{c}{ A szállodák kapacitása } & \multicolumn{2}{c}{$\begin{array}{c}\text { Az egy kiadó szobára jutó } \\
\text { szobaárbevétel }\end{array}$} & \multicolumn{2}{c}{ Szobaárbevétel } \\
\cline { 2 - 7 } & $\begin{array}{c}\text { A szállodák } \\
\text { száma }\end{array}$ & $\begin{array}{c}\text { A szállodai } \\
\text { szobák száma }\end{array}$ & Ft & $\begin{array}{c}\text { Budapesti } \\
\text { átlag }=100\end{array}$ & $\begin{array}{c}\text { Összesen } \\
\text { (millió Ft) }\end{array}$ & $\begin{array}{c}\text { Egy szállodára } \\
\text { (millió Ft) }\end{array}$ \\
\hline Budapest V. ker. & 34 & 4375 & 28071 & 174,8 & 44172 & 1299 \\
Budapest VII. ker. & 19 & 2399 & 18570 & 115,6 & 16213 & 853 \\
Budapest VIII. ker. & 19 & 1717 & 12003 & 74,7 & 7422 & 390 \\
Budapest VI. ker. & 17 & 1651 & 17174 & 106,9 & 10178 & 598 \\
Budapest XI. ker. & 13 & 1399 & 8600 & 53,5 & 4069 & 313 \\
Budapest I. ker. & 14 & 1287 & 17375 & 108,2 & 8173 & 583 \\
Budapest XIII. ker. & 11 & 1263 & 13011 & 81,0 & 6040 & 549 \\
Budapest XIV. ker. & 10 & 979 & 6703 & 41,7 & 2398 & 239 \\
Budapest IX. ker. & 11 & 942 & 9467 & 58,9 & 3184 & 289 \\
Budapest II. ker. & 9 & 759 & 10006 & 62,3 & 2796 & 310 \\
\hline Budapest összesen & 197 & 19397 & 16058 & 100,0 & 112454 & 570 \\
\hline
\end{tabular}

Megjegyzés: a kerületek a szállodai szobák száma alapján csökkenő sorrendben szerepelnek a táblázatban. Adatok forrása: $K S H$. 
elhanyagolható jelentőségűek (a fővárosi szállodai szobakapacitás kevesebb mint 14\%-ával). A külső kerületekben kevés szálloda működik, többségük a szerényebb minőségi kategóriához tartozik. Hét külső kerületben három vagy annál kevesebb hotel működik, kevés kiadó szobakapacitással, két kerületben pedig egyáltalán nincsen szálloda (KSH 2016). Budapesten a szállodai vendégéjszakák száma 8390029 volt 2016-ban, ennek csaknem a negyedét, 2065395 éjszakát az V. kerületi szállodákban töltötték el a vendégek. A vendégéjszakák száma is igazolja e szállodák sikeres telephelyválasztását (1. ábra). A további sorrend nagyon hasonlír a 2. táblázatban látható szobakapacitás-sorrendre, az eltérés annyi, hogy az I. kerületi és a XIII. kerületi szállodákban több éjszakát töltöttek el a vendégek, mint a XI. kerületben. A tíz legfontosabb kerülethez a budapesti szállodai vendégéjszakák 89\%-a köthető (KSH 2016).

A 3. táblázat a 2008 és 2016 között felépült új szállodákat mutatja: 52 új szállodával és 3275 új szállodai szobával növekedett Budapest szállodai kapacitása. A legtöbb új szálloda az V. kerületben nyílt meg, ami alátámasztja, hogy a

1. ábra: A szállodai vendégéjszakák száma a budapesti kerületekben (2016)

Guest nights in hotels in Budapest by districts (2016)

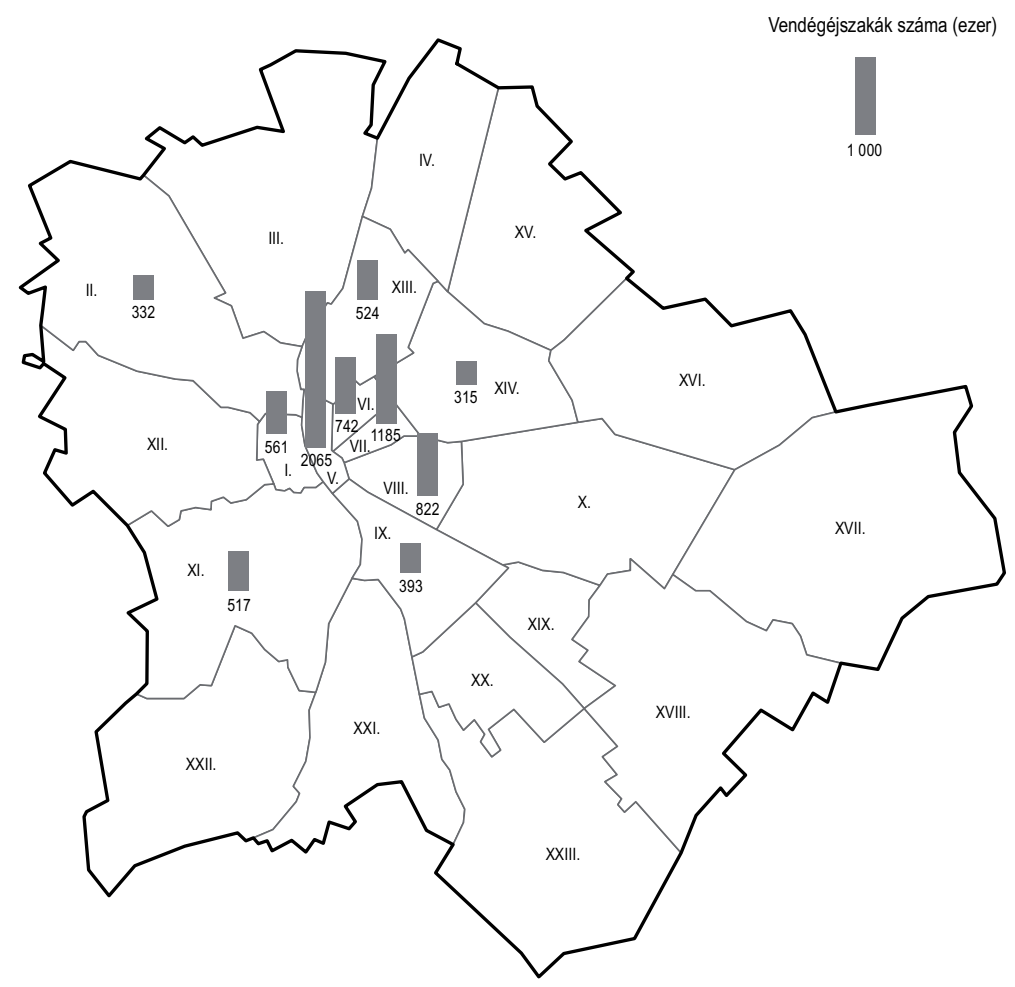

Adatok forrása: KSH. 
3. táblázat: A 2008 és 2016 között Budapesten nyitott új szállodák kerületi bontásban Hotels opened between 2008 and 2016, by districts of Budapest

\begin{tabular}{lcccccc}
\hline \multicolumn{1}{c}{ Kerület } & $\begin{array}{c}\text { A szállodák kapacitásának } \\
\text { növekedése }\end{array}$ & $\begin{array}{c}\text { Az egy kiadó szobárajutó } \\
\text { szobaárbevétel növekedése }\end{array}$ & \multicolumn{2}{c}{$\begin{array}{c}\text { A szobaárbevétel } \\
\text { növekedése }\end{array}$} \\
\cline { 2 - 7 } & $\begin{array}{c}\text { A szállodák } \\
\text { száma }\end{array}$ & $\begin{array}{c}\text { A szállodai } \\
\text { szobák száma }\end{array}$ & Ft & $\%$ & Millió Ft & $\%$ \\
\hline Budapest V. ker. & 19 & 1259 & 6858 & 32,3 & 19921 & 82,1 \\
Budapest VII. ker. & 7 & 716 & 5306 & 40,0 & 7814 & 93,0 \\
Budapest VIII. ker. & 8 & 565 & 5076 & 73,2 & 4589 & 262,0 \\
Budapest VI. ker. & 6 & 363 & 3206 & 22,9 & 3640 & 55,6 \\
Budapest XI. ker. & 0 & 106 & 2149 & 33,3 & 834 & 25,7 \\
Budapest I. ker. & 1 & 39 & 4490 & 34,8 & 2317 & 39,5 \\
Budapest XIII. ker. & 2 & -257 & 3042 & 30,5 & 583 & 10,6 \\
Budapest XIV. ker. & 0 & 35 & 1385 & 26,0 & 618 & 34,7 \\
Budapest IX. ker. & 3 & 211 & 830 & 9,6 & 864 & 37,2 \\
Budapest II. ker. & 3 & -73 & 3793 & 61,0 & 803 & 40,3 \\
\hline Budapest összesen & 52 & 3275 & 4714 & 41,5 & 45218 & 67,2 \\
\hline
\end{tabular}

Adatok forrása: KSH.

szállodai projektek tervezésekor a befektetők különös figyelmet fordítanak a telephely kiválasztására, és előnyben részesítik azokat a lehetséges területeket, ahol a hosszabb ideje óta működő szállodák is bizonyították sikerességüket.

A fóváros szállodai szempontból legsikeresebb területe az V., VI., VII., VIII. kerületek által határolt része. Itt valósult meg a legtöbb szállodai beruházás az utóbbi évtizedben, és továbbra is ezek a kerületek ajánlhatók leginkább új szállodaprojektek számára.

Az eredetileg más céllal, más funkcióval tervezett régebbi épületek szállodává történő átalakítására két jól ismert példa van a budapesti belvárosban. Az egyik a Deák téren, eredetileg a Budapesti Rendőr-főkapitányság egykori épülete, amelyet előbb a Le Meridien szállodalánc budapesti tagszállodájává alakították át, napjainkban pedig egy másik világhírủ szállodalánc, a Ritz-Carlton budapesti szállodája működik benne. A Lánchíd pesti hídfójénél található az egykori Gresham biztosítótársaság épülete, amely később sokáig lakóépületként is funkcionált. Manapság az egyik legismertebb luxusszállodákat üzemeltető szállodalánc - a Four Seasons - Gresham Palace szállodájának ad otthont. A belvárosban kevés foghíjtelek van, amely szálloda építésére alkalmas lenne, ezért egy meglévő épület szállodává alakítása vagy egy régi épület lebontása után új szálloda felépítése jöhet leginkább számításba.

A szállodaipar számára vonzónak mondató még az I. és a XIII. kerület, elsősorban a már régóta működő, többségében a Danubius szállodalánchoz tartozó szállodáinak köszönhetően. Annak ellenére, hogy Budapest 1923 óta fürdőváros, jelenleg csak három minősített gyógyszálloda (1. táblázat) üzemel a területén (ÁNTSZ 2017). 


\section{Összefoglalás}

A modern szállodaipar kialakulása óta az egységek telephelyválasztása az egyik legfontosabb kérdés, hiszen a kiválasztott hely a szálloda működésének teljes időtartamára befolyásolja működését és fejlesztési lehetőségeit. A telephelyválasztás modelljei közül több jól alkalmazható a szállodák estében is, e modellek alkalmazása hozzájárulhat a beruházási alternatívák értékeléséhez, illetve a telepítési döntésekhez kellő támpontot nyújthat.

A monocentrikus modell leíró elemzésekhez alkalmazható, döntően a városi szállodák telephelyválasztásánál. E szálláshelyek egyes altípusainak térbeli elhelyezkedését követhetjük nyomon a modellel, egyben egy-egy város szállodaiparának történeti és strukturális jellemzéséhez használhatjuk.

Az agglomerációs modellek nagyobb területek (térségek) szállodaipari értékelésére is alkalmasak. Piaci megoszlásokat, szállodaláncok és független szállodák telephelyválasztásának sajátosságait, a telepítés helyének a turisztikai vonzerőkkel való összefüggésrendszerét lehet elemezni általuk.

Az empirikus modellek számos indikátor összehasonlítására adnak lehetőséget. Alkalmazásuk korlátait legtöbbször az adatok elérhetősége jelenti, mert a szállodák gazdálkodási adatai üzleti és adatvédelmi okok miatt nem nyilvánosak, mindezeknek csak területileg összesített adatait lehet elemezni. Az egyik leggyakrabban használt változata ennek a típusnak a sikerességi modell. Az eljárás azokra a mutatószámokra épül, amelyek a leginkább utalnak a szállodák üzleti alapon számított kedvező, gazdaságos működésére, a versenytársakhoz képest magasabb bevételek elérésére. A modell alkalmas kisebb térségek vagy városi kerületek összehasonlítására, iránymutatást nyújthat a jövőbeni telepítési döntés meghozatalánál.

A gyakorlathoz közel álló múködési modellek - mint negyedik típus - a szállodák üzemeltetésének sajátosságait veszik figyelembe. A telepítési hely konkrét kiválasztásához a legfontosabb szempontokat állítják össze, a változók hierarchiája alapján értékelnek, segítve ezzel a befektetői döntéseket.

A szállodai telephelyválasztás tehát több modell segítségével leírható, értékelhető, de egyetlen eljárás sem mutatja meg önmagában a legjobb helyet. A telepítési döntéseknél egymásnak ellentmondó szempontok is felmerülhetnek, amelyeket figyelembe kell venni az optimális hely meghatározásához (Lengyel, Rechnitzer 2004).

Budapest szállodáinak telephelyválasztásait a monocentrikus és az empirikus modellek alkalmazásával értékeltük. A monocentrikus modell a városközpontból kiindulva feltárta a szállodai szempontból elkülöníthető fö területegységeket, így a belvárost, a városalközpontokat, és a külvárosokat, ahol különböző jellegü egységek találhatók. A belvárosban a Duna-parton és annak közelében múködnek a város legdrágább, legjobb egységei, a városalközpontokban a jó minőségü, de már kedvezőbb ár-érték arányúak találhatók. A városalközpontokra és a külvárosi terekre jellemzők a pályaudvari és konferenciaszállodák, a külön- 
leges szolgáltatást nyújtó, a repülőtéri és városszéli egységek. A monocentrikus modell alkalmazásával tehát képet kaphattunk a budapesti szállodák elhelyezkedéséről, a minőségi kategóriák, a jellemző szolgáltatások és a turisták szálláshelyválasztásának térbeli összefüggéseiről.

Egy szállodai beruházás konkrét helyének kiválasztásához átfogóbb elemzésre van szükség, amely értékeli a piaci versenyt, a versenytársak legfontosabb mutatóit. Erre alkalmas a tanulmányban bemutatott empirikus modell egyik változata, a sikerességi modell, amely kerületi szinten értékelte a fóváros szállodai szempontból kiemelkedő területeit, statikus és dinamikus szemléletben.

A 2016-ig kialakult budapesti szállodai struktúrát a belváros és a belső kerületek szállodáinak magas bevételei, üzleti sikerei kellően igazolták, mindezt alátámasztja az utóbbi évtized szállodaipari fejlesztési helyszíneinek bemutatása is.

Tanulmányunk alapján megállapíthatjuk, hogy Budapesten egy fejlődési szakasz fejeződött be, amely a magasabb igények kielégítését szolgálta, döntően a belső kerületek szállodaipari fejlesztésével. A nemzetközi tapasztalatok (Bécs, Madrid, Peking) alapján a jövőben a városmagtól távolabbi területek és a közlekedési csomópontok, bevásárlóközpontok környékének nagyobb mértékű szállodafejlesztései várhatók. A tanulmány a terjedelmi korlátok miatt nem tudott kitérni a társadalmi-gazdasági környezet hatáselemzésére, ami szintén befolyásolhatja a szállodai beruházás megvalósíthatóságát, a létesítendő egységek konkrét telephelyválasztását.

\section{Irodalom}

Aksoy, S., Ozbuk, M. Y. (2017): Multiple criteria decision making in hotel location: Does it relate to postpurchase consumer evaluations? Tourism Management Perspectives, 22., 73-81. http://doi.org/cr8s

Albert Tóth, A. (2011): Bécs és Budapest szállodaipara. In: Albert Tóth A., Darabos F. (szerk.): Nemzetközi turisztikai elemzések osztrák-magyar viszonylatban. Nyugat-magyarországi Egyetem, Győr, 62-69.

Albert Tóth, A. (2016): The impact of the hotel industry on the competitiveness of tourism destinations in Hungary. Journal of Competitiveness, 4., 85-104. http://doi.org/cr8t

ÁNTSZ (2017): Országos törzskönyvi nyilvántartás a magyarországi gyógyszálókról. Budapest, https://www.antsz.hu/felso_menu/ugyintezes/hatosagi_nyilvantartas/termeszetes_gyogytenyezok_ nyt/gyogyszallok.html?query=gy\%C3\%B3gysz\%C3\%A1ll\%C3\%B3 (Letöltés: 2017. december 21.)

Ashworth, G. J., Tunbridge, J. E. (1990): The tourist-historic city. Belhaven Press, London

Baum, J. A. C., Haveman, H. A. (1997): Love thy neighbor? Differentiation and agglomeration in the Manhattan hotel industry 1898-1990. Administrative Science Quarterly, 2., 304-338. http://doi.org/btcgz6

Bártfai E. (2007): A szállodaipar történeti és településszerkezeti összefüggései Budapesten. In: Tésits R., Tóth J., Papp J. (szerk.): Innovációk a térben: A munkavállalástól a rekreációig. Pécsi Tudományegyetem, Pécs, 117-140.

Bártfai E. (2012): Budapesti szállodatörténet 1896-1945 között. In: Aubert A., Gyuricza L., Huszti Zs. (szerk.): A kultúra turizmusa a turizmus kultúrája. IDResearch, Publikon, Pécs, 359-376.

Biemer, P. P., Kimes, S. E. (1991): An application of bootstrapping for determining a decision rule for site location. Journal of Business and Economic Statistics, 2., 189-196. http://doi.org/cr8v 
Buceková, I. (2009): A szállodák telephelyválasztása a város területén: Pozsony (Bratislava) esete. In: Michalkó G., Rátz T. (szerk.): A tér vonzásában: a turisztikai termékfejlesztés térspecifikus vonásai. Kodolányi János Főiskola, MTA Földrajztudományi Kutatóintézet, Magyar Földrajzi Társaság, Székesfehérvár, Budapest, 144-157.

Bull, O. A. (1994): Pricing a motel's location. International Journal of Contemporary Hospitality Management, 6., 10-15. http://doi.org/drt9ff

Chung, W., Kalnins, A. (2001): Agglomeration effects and performance: a test of the Texas lodging industry. Strategic Management Journal, 10., 969-988. http://doi.org/dm2mrw

Egan, D. J., Nield, K. (2000): Towards a theory of intraurban hotel location. Urban Studies, 3., 611-621. http://doi.org/bpk8v6

Emir, O., Saracli, S. (2014): Determination of the thermal hotel location: application of analytic hierarchy process. Tourism and Hospitality Management, 1., 71-83.

Enz, C.A., Canina, L., Liu, Z. (2008): Competitive dynamics and pricing behavior in US hotels: the role of co-location. Scandinavian Journal of Hospitality and Tourism, 3., 230-250. http://doi.org/fj47md

Gray, S. W., Liguori, C. S. (1990): Hotel and motel management and operations. Prentice Hall, New Jersey

Gee, Y. C. (1996): Resort development and management. Educational Institute, American Hotel \& Lodging Association, Lansing

Go, M. F., Pine, R. (1995): Globalisation strategy in the hotel industry. Routledge. London

Győrffy A. (2004): Szállodatan I-II., Nemzeti Tankönyvkiadó Rt., Budapest

Hayes, K. D., Ninemeier, D. J. (2004): Hotel operations management. Pearson Education, Upper Saddle River

Jávor J. (2008): Korszerű szállásszolgáltatás. Képzőművészeti Kiadó, Budapest

Jones, P., Lockwood, A. (2004): The management of hotel operations. Thomson Learning, London

Kátay Á. (2011): Sikertényező-e a wellness szállodák telepítési helye? In: Michalkó G., Rátz T., (szerk.): A turizmus dimenziói: humánum, ökonómikum, politikum. Kodolányi János Főiskola, Székesfehérvár, 207-221.

Kovács I. (2009): A szálloda mint termék. In: Papp I. (szerk.): Szálloda-és vendéglátásmenedzsment. Budapesti Corvinus Egyetem, Budapest, 45-82.

KSH (2008-2016): Tájékoztatási adatbázis. Budapest

Lengyel I., Rechnitzer J. (2004): Regionális gazdaságtan. Dialóg Campus Kiadó, Budapest, Pécs

Lundberg, E. D. (1994): The hotel and restaurant business. Van Nostrand Reinhold, New York

Medlik, S. (1966): Market feasibility approach to hotel location. The Tourist Review, 4., 141-148. http://doi.org/chrgtr

Newell, G., Seabrook, R. (2006): Factors influencing hotel investment decision making. Journal of Property Investment \& Finance, 4., 279-294. http://doi.org/bpgjxv

Pandit, N. S. (1986): Hotel project - Feasibility evaluation. Service-Fachverlag an der Wirtschaftsuniversität Wien, Wien

Park, E. M., Kim, Y. O. (2012): An analysis of urban hotel location focusing on market segment and local \& foreign guest preference. In: Greene, M., Reyes, J., Castro, A., (eds.): Proceedings: Eighth International Space Syntax Symposium, Santiago de Chile, paper ref. 8111.

Porter, M. E. (1990): The competitive advantage of nations. The Free Press, New York http://doi.org/bss3

Rubovszky A. (2009): A magyar szállodaipar története a II. világháború után. In: Rubovszky A., Szigeti A., Walkó M. (szerk.): A magyar vendéglátás és turizmus újkori története. Szaktudás Kiadó Ház, Budapest, 338-357.

Rushmore, S., O’Neill, W. J., Rushmore, S. Jr. (2012): Hotel market analysis and valuation. Appraisal Institute, Chicago

Shoval, N. (2006): The geography of hotels in cities: an empirical validation of a forgotten model. Tourism Geographies, 1., 56-75. http://doi.org/bf7tsx

Smith, S. L. J. (1995): Tourism analysis: A handbook. Longman, Harlow

Tsang, E. W. K., Yip, P. S. L. (2009): Competition, agglomeration, and performance of Beijing hotels. Service Industries Journal, 2., 155-171. http://doi.org/dcf6j6

Urtasun, A., Gutiérrez, I. (2006): Hotel location in tourism cities: Madrid 1936-1998. Annals of Tourism Research, 2., 382-402. http://doi.org/fgfww5 
Vadas G. (2006): Szálláshelyek, szállodák. KIT Kft., Heller Farkas Gazdasági és Turisztikai Szolgáltatások Főiskolája, Budapest

Yang, Y., Luo, H., Law, R. (2014): Theoretical, empirical, and operational models in hotel location research. International Journal of Hospitality Management, 36., 209-220. http://doi.org/f5r7zp

Yang, Y., Tang, J., Luo, H., Law, R. (2015): Hotel location evaluation: A combination of machine learning tools and web GIS. International Journal of Hospitality Management, 47., 14-24. http://doi.org/f7fwg6

Yang, Y., Wong, K. F., Wang, T. (2012): How do hotels choose their location? Evidence from hotels in Beijing. International Journal of Hospitality Management, 31., 675-685. http://doi.org/c9mfnb

Yokeno, N. (1968): La localisation de l'industrie touristique: application de l'analyse de Thunen-Weber. C.H.E.T., Aix-en-Provence (Cahiers du Tourisme)

Zhang, H. Q., Guillet, B. D., Gao, W. (2012): What determines multinational hotel groups' locational investment choice in China? International Journal of Hospitality Management, 2., 350-359. http://doi.org/dwbmk3 